\section{In Vitro Shoot Regeneration and Polyploid Induction from Leaves of Hypericum Species}

\author{
Elisabeth M. Meyer, Darren H. Touchell ${ }^{1}$, and Thomas G. Ranney \\ Department of Horticultural Science, Mountain Horticultural Crops \\ Research and Extension Center, North Carolina State University, 455 \\ Research Drive, Mills River, NC 28759-3423
}

Additional index words. Hypericum frondosum, Hypericum galioides, Hypericum kalmianum, meta-topolin, oryzalin, endoreduplication

\begin{abstract}
Hypericum L. H2003-004-016 is a complex hybrid among Hypericum frondosum Michx., Hypericum galioides Lam., and Hypericum kalmianum L. and exhibits valuable ornamental characteristics, including compact habit, bluish green foliage, and showy flowers. Inducing polyploidy may further enhance the ornamental traits of this hybrid and provide new opportunities for hybridizing with other naturally occurring polyploid Hypericum sp. In this study, in vitro shoot regeneration and treatment of regenerative callus with the dinitroaniline herbicide oryzalin (3,5-dinitro-N4,N4-dipropylsufanilamide) were investigated as a means of inducing allopolyploidy. First, in vitro regeneration was optimized for callus and shoot induction by culture of leaf explants on medium supplemented with benzylamino purine (BA) or meta-topolin $(\mathrm{mT})$ at 5,10 , or $15 \mu \mathrm{M}$ in combination with indoleacetic acid (IAA) at $0,1.25,2.5$, or $5 \mu \mathrm{M}$. Both BA and mT treatments successfully induced regenerative callus and shoots. Multiple regression analysis estimated maximum regenerative callus $(94 \%)$ and shoot induction (18 shoots per explant) in medium supplemented with $5 \mu \mathrm{M}$ BA and $3.75 \mu \mathrm{M}$ IAA. In the second part of the study, exposure of regenerative callus to oryzalin at $0,7.5,15,30,60$, or $90 \mu \mathrm{M}$ for durations of 3,6 , or $9 \mathrm{~d}$ was investigated for polyploid induction. There was no survival for any of the calli in the 60- or $90-\mu \mathrm{M}$ oryzalin treatments, but calli subjected to the other treatments exhibited some survival and polyploid induction. Duration had no effect on callus survival or ploidy level, but oryzalin concentration was a significant factor in both. The greatest percentage $(44 \%)$ of polyploids was induced with $30 \mu \mathrm{M}$ oryzalin. Spontaneous chromosome doubling was observed in $8 \%$ of control explants receiving no oryzalin treatment.
\end{abstract}

The genus Hypericum L. comprises $\approx 370$ species worldwide that are well known for their pharmaceutical qualities. Several species, including Hypericum frondosum Michx., Hypericum galioides Lam., and Hypericum kalmianum L., also have desirable ornamental characteristics and environmental tolerances that make them promising species for breeding and improvement (Coulter, 1886; Hasselkus, 1998; Touchell et al., 2008). All three species demonstrate broad adaptability and have showy, gold-colored flowers. In addition to attractive flowers, $H$. frondosum 'Sunburst' also has bluish green foliage and

Received for publication 12 June 2009. Accepted for publication 13 Aug. 2009.

This research was funded, in part, by the North Carolina Agricultural Research Service, Raleigh, NC.

Use of trade names in this publication does not imply endorsement by the NCARS of the products named nor criticism of similar ones not mentioned. Technical assistance of Jeremy Smith, Joel Mowrey, and Nathan Lynch is gratefully acknowledged.

This manuscript is from a thesis submitted by Elisabeth Meyer in partial fulfillment of the requirements for the MS degree.

${ }^{1}$ To whom reprint requests should be addressed; e-maildarren_touchell@ncsu.edu. a compact growth form. Although generally more open in habit than the other two species, H. kalmianum has the desirable characteristic of being cold-hardy to U.S. Department of Agriculture Zone 4. Hypericum galioides 'Brodie' is particularly tolerant of the hot, humid conditions in the southeastern United States. At the North Carolina State Mountain Horticultural Crops Research and Extension Center (MHCREC) in Mills River, NC, these three species have been crossed, through multiple generations, to develop hybrid H2003-004-016, an openpollinated seedling from hybrid H2001-090 $[H$. frondosum $\times(H$. galioides 'Brodie' $\times H$. kalmianum)]. The hybrid exhibits a dense, compact growth form, narrow, bluish green foliage, and an abundance of showy, goldcolored flowers.

In addition to applications in basic propagation, tissue culture can be a useful tool in improvement of ornamental features. Development of in vitro regeneration systems provides an ideal foundation for further improvements by ploidy manipulations, mutation treatments, and transgenic applications. Previous in vitro regeneration studies of Hypericum have focused on medicinal species, including $H$. perforatum L. (Franklin and Dias, 2006; McCoy and Camper, 2002;
Murch et al., 2000; Pretto and Santarém, 2000), $H$. heterophyllum Vent. (Ayan and Crak, 2006), and H. brasiliense Choisy (Cardoso and de Oliveira, 1996). Other species have been regenerated in vitro as a conservation effort such as H. foliosum [Dryand.] (Moura, 1998). However, little work has been done to develop in vitro techniques for ornamental Hypericum species with the exception of H. frondosum (Touchell et al., 2008).

In vitro regeneration from leaves of Hypericum sp. characteristically requires a high cytokinin:auxin ratio (Moura, 1998; Santarém and Astarita, 2003). Specifically, work with $H$. frondosum, a parent of $\mathrm{H} 2003$ 004-016, shows high levels of benzylamino purine (BA) facilitate optimum in vitro regeneration from leaves (Touchell et al., 2008). Benzylamino purine is the most commonly used cytokinin for in vitro regeneration of Hypericum sp. However, BA has been associated with inducing somaclonal variation (Siragusa et al., 2007) and hyperhydricity (Bairu et al., 2007; Rossetto et al., 1992) in some crops, which may negatively influence the quality of regenerated shoots. In comparison, meta-topolin (mT) is a naturally occurring cytokinin with a similar aromatic structure to BA and has not been linked with somaclonal variation or hyperhydricity (Bairu et al., 2007; Werbrouck et al., 1996), but there is a need for more extensive research of its long- and short-term effects on plant in vitro cultures. Meta-topolin may have potential as a highly active alternative to BA. Although $\mathrm{mT}$ has not been used with Hypericum sp., it has shown promise in regeneration of Spathiphyllum floribundum N.E.Br. (Werbrouck et al., 1996), Musa AAB L. (Roels et al., 2005), Aloe polyphylla Schönland ex Pillans (Bairu et al., 2007), and Pelargonium $\times$ hederaefolium 'Bonete' Salisb. (Wojtania et al., 2004).

Several auxins have been used in regeneration of Hypericum sp., including indoleacetic acid (IAA) (Ayan and Crak, 2006; Cardoso and de Oliveira, 1996; Franklin and Dias, 2006; Touchell et al., 2008; Wang et al., 2007), $\alpha$-naphthaleneacetic acid (Cardoso and de Oliveira, 1996; Moura, 1998; Wang et al., 2007), and 2,4-dichlorophenoxyacetic acid (2,4-D) (Ayan and Crak, 2006; Cardoso and de Oliveira, 1996; Pretto and Santarém, 2000; Wang et al., 2007). However, recent work with one of the parents of hybrid H2003-004-016, H. frondosum 'Sunburst', has shown 2,4-D to be ineffective for in vitro shoot regeneration (Touchell et al., 2008).

Efficient in vitro regeneration systems provide a tool to manipulate ploidy and improve ornamental features. Polyploidy in some plants may result in desirable ornamental characteristics such as larger, longerlasting flowers, thicker petals, and larger, thicker leaves (Kehr, 1996). In addition, polyploid plants, particularly allopolyploids, can have other advantageous traits such as enhanced vigor, improved pest resistance and stress tolerance, and protection from deleterious mutations resulting from gene redundancy (Comai, 2005; Ranney, 2006). 
Various mitotic inhibitors have been used to induce polyploidy in in vitro systems such as colchicine [N-(5,6,7,9-tetrahydro-1, 2,3,10-tetra-methoxy-9-oxobenzo(a)heptalen7-yl] acetamide. However, the dinitroaniline herbicide oryzalin (3,5-dinitro-N4,N4dipropylsufanilamide) is often preferred to colchicine for use in polyploidy induction in plants as a result of its lower toxicity (van Tuyl et al., 1992), effectiveness at lower concentrations (Morejohn et al., 1987; Väinölä, 2000; van Tuyl et al., 1992), and tendency to produce plants without deformed tissue or abnormal growth (van Tuyl et al., 1992). For example, in Lilium L., $150 \mu \mathrm{M}$ oryzalin treatments induced more polyploids than colchicine at $2.5 \mathrm{~mm}$ (van Tuyl et al., 1992). Lilium sp. treated with oryzalin also exhibited fewer growth abnormalities than those treated with colchicine. Similarly, oryzalin treatments (30 $\mu \mathrm{M}$ or $150 \mu \mathrm{M})$ of Rhododendron $\mathrm{L}$. yielded $45 \%$ polyploids as opposed to $15 \%$ with colchicine treatments $(0.625 \mathrm{~mm}$ or 1.25 mм) (Väinölä, 2000). Previous work with polyploid induction in Hypericum is limited to $H$. perforatum and only uses colchicine (Wang et al., 2007). Therefore, to improve Hypericum H2003-004-016 for release as a new ornamental hybrid and to provide a foundation for future work in in vitro regeneration and ploidy manipulation of Hypericum taxa, the objectives of this study were to 1) develop an effective shoot regeneration protocol for Hypericum H2003-004-016 from leaf explants; and 2) establish a reliable procedure for in vitro induction of polyploidy in this hybrid using oryzalin.

\section{Materials and Methods}

Plant material and regeneration protocols. Young leaves of Hypericum H2003-004-016 were collected from four greenhouse-grown stock plants at the MHCREC and surfacesterilized with a $20 \%$ commercial bleach solution $(1.3 \% \mathrm{NaOCl})$ for 17 min under a laminar flow hood followed by three rinses of 5 min each in sterile distilled water. Leaf explants $\left(5 \mathrm{~mm}^{2}\right)$ were placed abaxial side down in petri dishes containing medium composed of Murashige and Skoog (MS) basal salts and vitamins (Murashige and Skoog, 1962), 3\% sucrose, and solidified with $0.8 \%$ agar. Media was supplemented with either BA or $\mathrm{mT}$ at 5 , 10 , or $15 \mu \mathrm{M}$ in combination with IAA at 0 , $1.25,2.5$, or $5 \mu \mathrm{M}$. Plates were incubated in the dark at $23 \pm 2{ }^{\circ} \mathrm{C}$.

Each set of cytokinin treatments was treated as a separate experiment with a completely randomized design. There were at least seven replicates (plates) per treatment and five subsamples (leaf explants) per replicate. After 5 weeks, data were collected on the percentage of leaf explants producing regenerative callus and number of shoots induced per leaf explant. Data were subjected to analysis of variance (ANOVA) and multiple regression analyses (Proc GLM, SAS Version 9.1; SAS Inst., Cary, NC).

Polyploid induction. Regenerative calli maintained on solid MS media supplemented with $10 \mu \mathrm{M}$ BA and $2.5 \mu \mathrm{M}$ IAA were submerged in a liquid MS medium supplemented with $3 \%$ sucrose and oryzalin at 0 , $7.5,15,30,60$, or $90 \mu \mathrm{M}$ and placed in the dark on a rotating shaker $(80 \mathrm{rpm})$ for a duration of 3,6 , or $9 \mathrm{~d}$. A stock solution of $1 \mathrm{~mm}$ oryzalin was dissolved in ethanol, filter-sterilized, and added to cooled autoclaved media. An equivalent amount of ethanol was added to all control treatments. An additional control, receiving no oryzalin treatment and no submersion in liquid media, was also included $(0 \mathrm{~d})$. After treatment with oryzalin, calli received three rinses of $5 \mathrm{~min}$ each with sterile distilled water before being transferred back onto medium of the same formulation on which they were originally cultured. The experiment was a completely randomized design with six replicates (plates) per treatment and five subsamples (leaf explants) per replicate. After $\approx 5$ weeks, survival data were recorded for each treatment and subjected to ANOVA and multiple regression analysis (Proc GLM, SAS Version 9.1; SAS Inst.).

Approximately 4 months after treatment, ploidy of shoots was determined using flow cytometry. One shoot was finely chopped with a double-sided razor blade in a petri dish with $400 \mu \mathrm{L}$ of nuclei extraction buffer (CyStain ultraviolet Precise P Nuclei Extraction Buffer ${ }^{\circledR}$; Partec, Münster, Germany). The solution was filtered through Partec CellTrics $^{\mathrm{TM}}$ disposable filters with a pore size of $50 \mu \mathrm{m}$ to remove tissue debris. Nuclei were stained with $1.2 \mathrm{~mL} \mathrm{4}$ ', 6-diamidino2-phenylindole staining buffer (CyStain ultraviolet Precise P Staining Buffer; Partec). Stained nuclei were analyzed with a flow cytometer (Partec PA II; Partec). Ploidy level was determined by comparing peak position of a diploid shoot of Hypericum H2003-004-
016 with peak position of each sample. Three shoots (subsamples) were analyzed from each replicate for each treatment, including the control. Three leaves from each of the four stock plants were also analyzed to ensure diploid homogeneity of the source material. Data were subjected to ANOVA and multiple regression analyses (Proc GLM, SAS Version 9.1; SAS Inst.).

\section{Results and Discussion}

Regeneration protocols. Induction of regenerative callus and shoots was achieved in vitro for Hypericum H2003-004-016. Shoots were induced from callus in all treatments combining BA with IAA. In the mT treatments, all treatments induced shoots except for $5 \mu \mathrm{M} \mathrm{mT}+0 \mu \mathrm{M}$ IAA, $10 \mu \mathrm{M} \mathrm{mT}+0 \mu \mathrm{M}$ IAA, $15 \mu \mathrm{M} \mathrm{mT}+0 \mu \mathrm{M}$ IAA, and $15 \mu \mathrm{M}$ $\mathrm{mT}+1.25 \mu \mathrm{M}$ IAA.

Regression analysis demonstrated BA and IAA concentrations and their interaction had a significant effect on induction of regenerative callus and number of shoots $(P<0.05)$ (Figs. 1 and 2). Both induction of regenerative callus and number of shoots had a linear response to $\mathrm{BA}$ concentration and the interaction between BA and IAA as well as a quadratic response to IAA concentration. Based on regression analysis, 18 shoots per explant were predicted as the optimum for the treatment combination $5 \mu \mathrm{M}$ BA $+3.75 \mu \mathrm{M}$ IAA (Figs. 1 and 2). In contrast, Touchell et al. (2008) reported the optimal treatment for regeneration of shoots of $H$. frondosum was $10 \mu \mathrm{M} \mathrm{BA}+2.5 \mu \mathrm{M}$ IAA.

Regression analysis of treatments using $\mathrm{mT}$ in combination with IAA indicated $\mathrm{mT}$ and IAA concentrations had a significant effect on induction of regenerative callus $(P<0.05)$ and number of shoots per explant

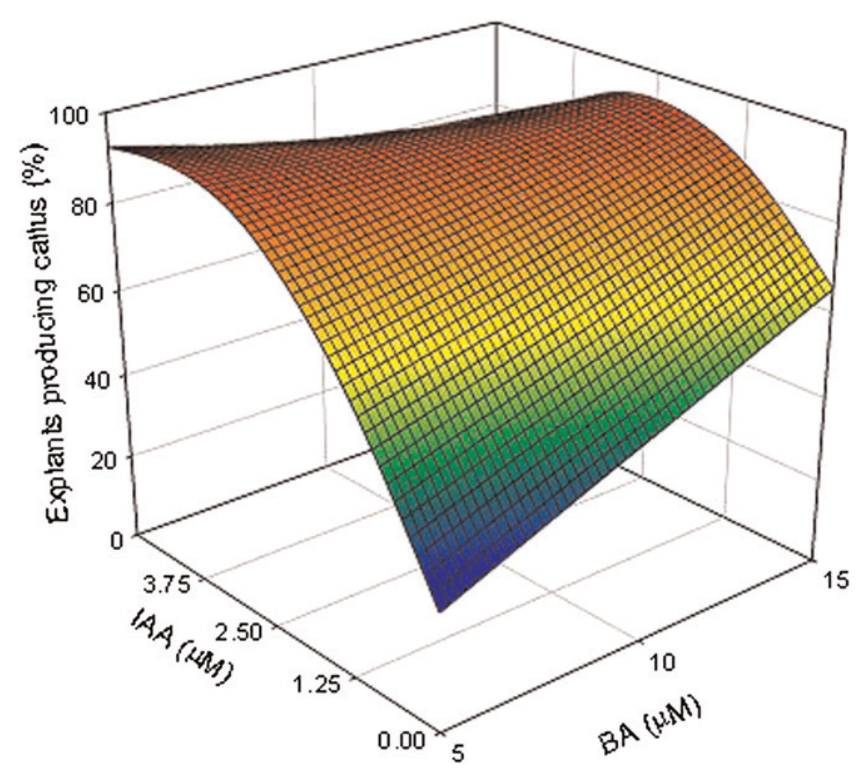

Fig. 1. Effect of BA and IAA on percentage of leaf explants producing regenerative callus. Data points are predicted percentages of regenerative callus based on a general linear model: $y=0.082+0.037(\mathrm{BA})+$ $0.398(\mathrm{IAA})-0.0415\left(\mathrm{IAA}^{2}\right)-0.0123(\mathrm{BA})(\mathrm{IAA}), P<0.001, r^{2}=0.83$. BA $=$ benzylamino purine; $\mathrm{IAA}=$ indoleacetic acid. 
$(P<0.10)$ (Figs. 3 and 4$)$. Induction of regenerative callus and number of shoots per explant both decreased linearly with increasing $\mathrm{mT}$ concentration. In relation to IAA concentration, induction of regenerative callus had a quadratic response, whereas number of shoots decreased linearly as IAA increased. The optimal treatment in the $\mathrm{mT}$ experiment was $5 \mu \mathrm{M} \mathrm{mT}+5 \mu \mathrm{M}$ IAA, which induced $\approx 10$ shoots per explant. Thus, $\mathrm{mT}$ can be used successfully as a cytokinin in an in vitro regeneration system for Hypericum $\mathrm{H} 2003$ 004-016. Other systems using $\mathrm{mT}$ produced more large shoots, greener shoots, more successful rooting both in vitro and ex vitro, better acclimatization ex vitro, less abnormal growth, and less hyperhydricity than plantlets produced using BA (Bairu et al., 2007; Werbrouck et al., 1996). A higher number of longer, thicker shoots was also observed in $\mathrm{mT}$ treatments of this study when compared with BA treatments (personal observation, data not presented).

Polyploid induction. Hypericum H2003004-016 had a 2C DNA content of $0.8 \rho \mathrm{g} \pm$ 0.01 (mean \pm SEM, $\mathrm{n}=7$ ) consistent with a diploid (Brutovská et al., 1998; Matzk et al., 2003). Mixoploids $(2 x+4 x)$ and tetraploids

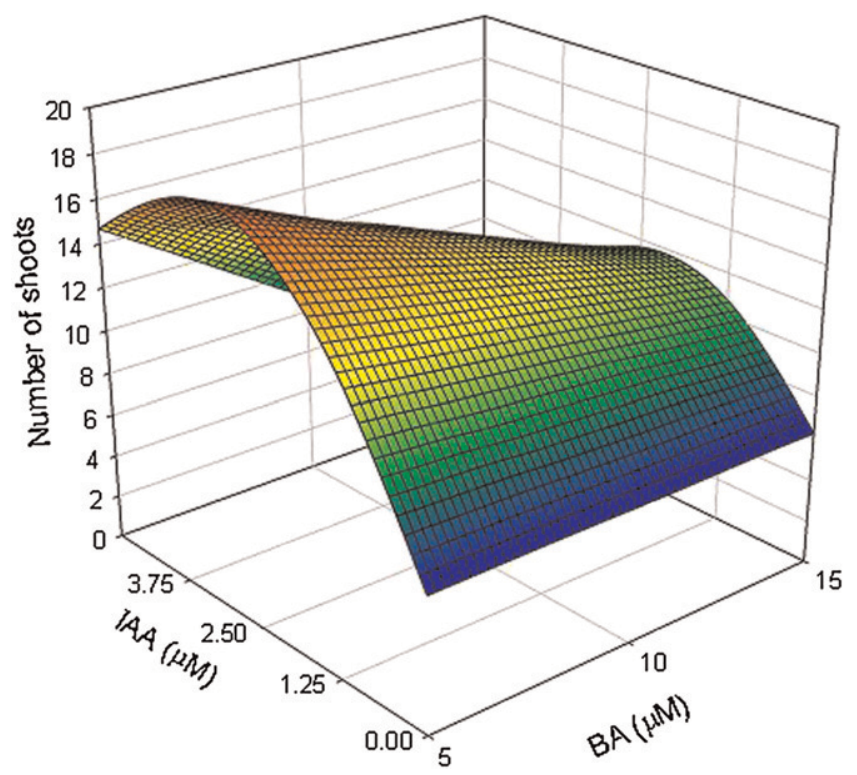

Fig. 2. Effect of BA and IAA on number of regenerated shoots per leaf explant. Data points are predicted values for number of shoots based on a general linear model: $\mathrm{y}=6.25-0.0014(\mathrm{BA})+8.58$ (IAA) -1.14 $\left(\mathrm{IAA}^{2}\right)-0.24(\mathrm{BA})(\mathrm{IAA}), P<0.05, r^{2}=0.61 . \mathrm{BA}=$ benzylamino purine; IAA $=$ indoleacetic acid.

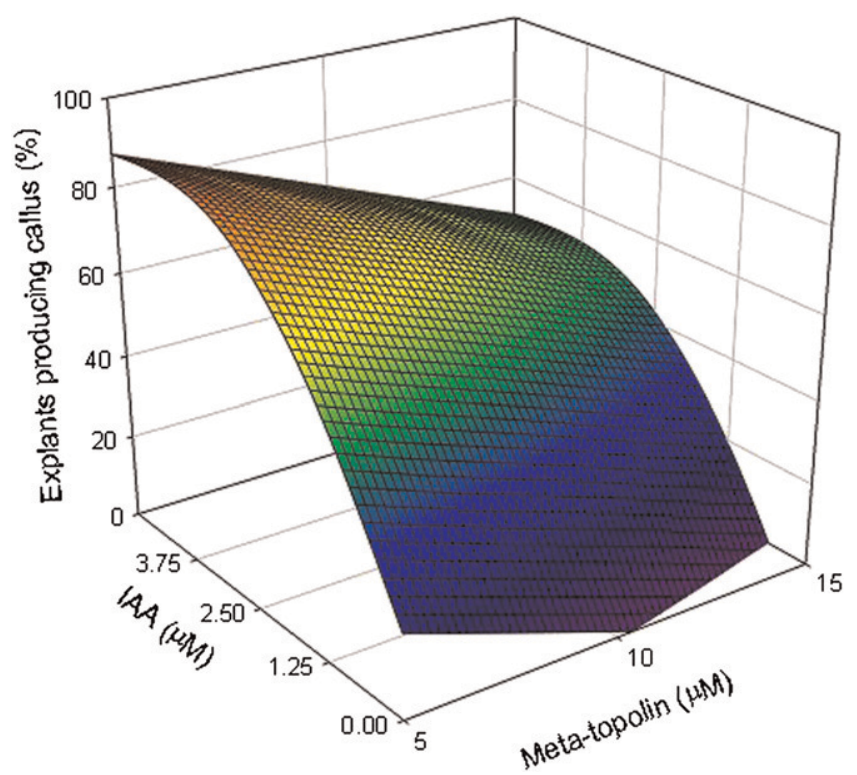

Fig. 3. Effect of $\mathrm{mT}$ and IAA on percentage of leaf explants producing regenerative callus. Data points are predicted percentages of regenerative callus based on a general linear model: $y=0.38-0.037(\mathrm{mT})+$ $0.34(\mathrm{IAA})-0.041\left(\mathrm{IAA}^{2}\right), P<0.05, r^{2}=0.81 . \mathrm{mT}=$ meta-topolin; IAA $=$ indoleacetic acid .

(4x) were successfully induced by the use of oryzalin. Oryzalin concentration affected shoot survival and ploidy level, but there were no effects of treatment duration on these variables (data not shown). All calli exposed to 60 or $90 \mu \mathrm{M}$ oryzalin died. Survival of calli exposed to $0,7.5,15$, or $30 \mu \mathrm{M}$ oryzalin exhibited a quadratic response to oryzalin concentration $(P<0.01)$ (Fig. 5). The percentage of diploids had a negative linear relationship with increasing oryzalin concentration $(P<0.01)$, whereas percentage of homogenous tetraploids had a positive linear relationship $(P<0.05)$ (Fig. 5). Percentage of mixoploids demonstrated a quadratic response to oryzalin concentration $(P<0.10)$ (Fig. 5). The greatest percentage of homogenous tetraploids was $\approx 35 \%$ and occurred in the $30 \mu \mathrm{M}$ oryzalin treatment. One octoploid was also induced in the $30 \mu \mathrm{M}, 3-\mathrm{d}$ treatment (data not presented).

Unexpectedly, the untreated controls across all durations, including the 0 -d duration control not submerged in liquid medium, also induced tetraploids $(8 \%)$. This spontaneous chromosome doubling may have resulted from endoreduplication taking place either in cells of the original stock plant tissue or within the in vitro regeneration system. During endoreduplication, multiple, uniform copies of chromosomes are produced without segregation or cytokinesis as a result of oscillation of cyclin-dependent kinase (CDK) activity during the S-phase and lack of CDK activity during the M-phase (Grafi and Larkins, 1995; Larkins et al., 2001). Because analysis by flow cytometry showed the leaf tissue from the four original plants to be diploid, it is possible in vitro regeneration promoted spontaneous chromosome doubling. Occurrence of endoreduplication has been linked to cellular cytokinin and auxin levels (Larkins et al., 2001; Valente et al., 1998), both of which were increased in the in vitro system. This process has been reported in a wide variety of plants, including Solanum L. (Chauvin et al., 2003), Humulus lupulus L. (Škof et al., 2007), Rosa hybrida L. (Moyne et al., 1993), Doritaenopsis Guillaumin (Mishiba et al., 2001), and Zea mays L. (Antoine-Michard and Beckert, 1997; Grafi and Larkins, 1995). Consistent with other studies in which endoreduplication occurred in vitro (Chauvin et al., 2003; Škof et al., 2007), the controls in the present investigation did not induce any mixoploids.

It is also possible that endoreduplication occurred in the stock plant tissue before it was placed in tissue culture. The condition in which the same plant contains cells of different ploidy levels as a result of endoreduplication is known as endopolyploidy and occurs in 90\% of angiosperms (D'Amato, 1984). Endopolyploidy occurs at different levels among species and with varying frequency among different organs and tissues within the same plant (Barow, 2006). In leaves, endopolyploidy has been shown to vary among the base, middle, and tip of the leaf (Cionini et al., 1983; Lim and Loh, 2003; Pyke et al., 1991). Although flow cytometry of leaves from the stock plants showed them 


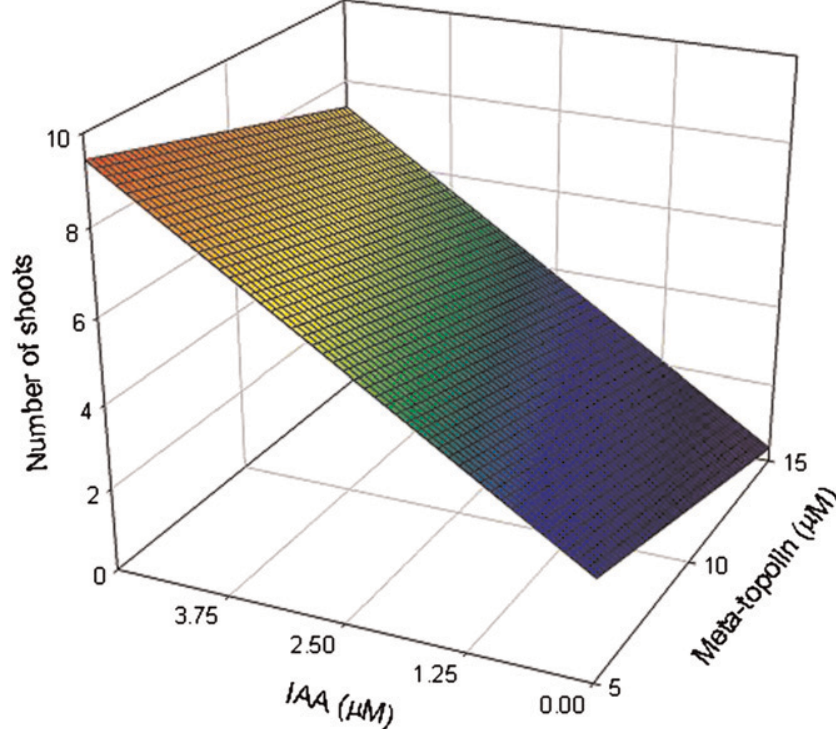

Fig. 4. Effect of $\mathrm{mT}$ and IAA on number of shoots per leaf explant. Data points are predicted values for number of shoots based on a general linear model: $\mathrm{y}=3.49-0.21(\mathrm{mT})+1.49$ (IAA), $P<0.05, r^{2}=0.49$. $\mathrm{mT}=$ meta-topolin; IAA $=$ indoleacetic acid.

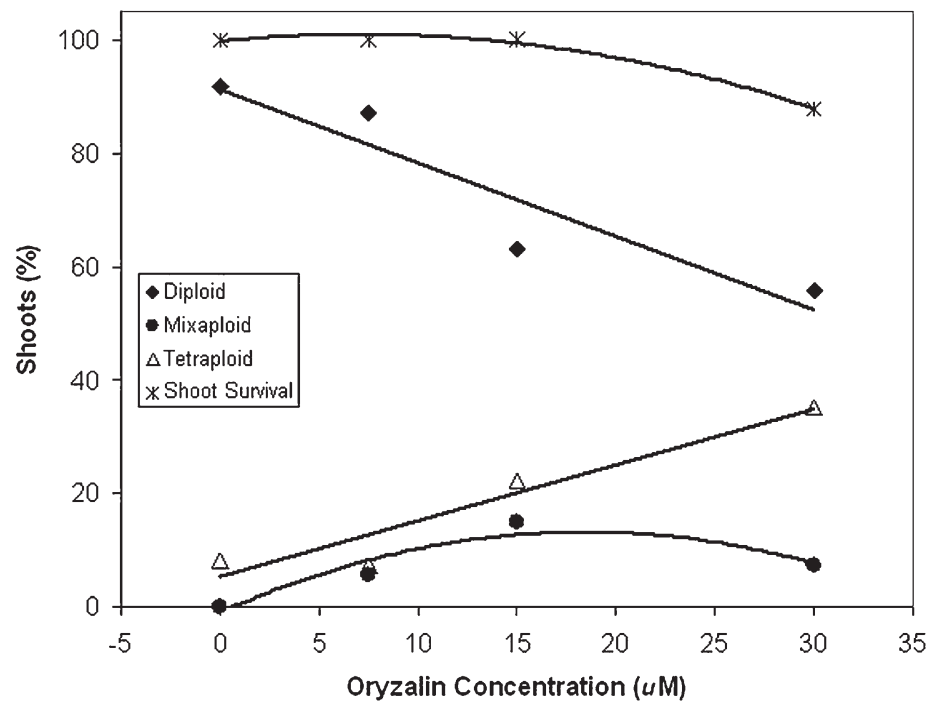

Fig. 5. Effect of oryzalin concentration on percentage shoot survival and ploidy level. Solid lines represent trends fitted using linear and quadratic regression analyses: shoot survival $(*)=1.01-0.00014 \mathrm{x}^{2}, r^{2}=$ $0.74, P<0.01$; diploid $(\bullet)=0.91-0.013 \mathrm{x}, r^{2}=0.70, P<0.01$; mixoploid $(\bullet)=-0.0077+0.015 \mathrm{x}-$ $0.0004 \mathrm{x}^{2}, r^{2}=0.37, P<0.10$; tetraploid $(\Delta)=0.06+0.0096 \mathrm{x}^{2}, r^{2}=0.44, P<0.05$.

to be diploid, it is feasible that if only a few indistinguishable polyploid cells were present, they may have regenerated into tetraploid plants in the controls.

In conclusion, effective protocols for in vitro regeneration and polyploidy induction were developed that provides a foundation for further work on tissue culture and ploidy manipulation for diverse Hypericum species and cultivars. These protocols provide a platform for future studies on genetic improvement projects, including mutation treatments and transgenic applications. The new population of polyploids developed in this study have potential usefulness in future breeding projects, for genomic studies of nascent polyploids, and as new commercial selections.

\section{Literature Cited}

Antoine-Michard, S. and M. Beckert. 1997. Spontaneous versus colchicine-induced chromosome doubling in maize anther culture. Plant Cell Tissue Organ Cult. 48:203-207.

Ayan, A.K. and C. Crak. 2006. In vitro multiplication of Hypericum heterophyllum, an endemic Turkish species. Amer. J. Plant Pathol. 1:76-81.

Bairu, M.W., W.A. Stirk, K. Dolezal, and J.V Staden. 2007. Optimizing the micropropagation protocol for the endangered Aloe polyphylla: Can meta-topolin and its derivatives serve as replacement for benzyladenine and zeatin? Plant Cell Tissue Organ Cult. 90:15-23.

Barow, M. 2006. Endopolyploidy in seed plants. Bioessays 28:271-281.

Brutovská, R., E. Čellárová, and J. Doležel. 1998. Cytogenetic variability of in vitro regenerated
Hypericum perforatum L. plants and their seed progenies. Plant Sci. 133:221-229.

Cardoso, M.A. and D.E. de Oliveira. 1996. Tissue culture of Hypericum brasiliense Choisy: Shoot multiplication and callus induction. Plant Cell Tissue Organ Cult. 44:91-94.

Chauvin, J.E., C. Souchet, J.P. Dantec, and D. Elissèche. 2003. Chromosome doubling of $2 x$ Solanum species by oryzalin: Method development and comparison with spontaneous chromosome doubling in vitro. Plant Cell Tissue Organ Cult. 73:65-73.

Cionini, P.G., A. Cavallini, S. Baroncelli, B. Lercai, and F. D'Amato. 1983. Diploidy and chromosome endoreduplication in the development of epidermal cell lines in the first foliage leaf of durum wheat (Triticum durum Desf.). Protoplasma 118:36-43.

Comai, L. 2005. The advantages and disadvantages of being polyploid. Nat. Rev. Genet. 6:836846.

Coulter, J.M. 1886. Revision of North American Hypericaceae. Bot. Gaz. 11:78-88.

D'Amato, F. 1984. Role of polyploidy in reproductive organs and tissues, p. 519-566. In: Jori, B.M. (ed.). Embryology of angiosperms. Springer Verlag, New York, NY.

Franklin, G. and A.C.P. Dias. 2006. Organogenesis and embryogenesis in several Hypericum perforatum genotypes. In Vitro Cell. Dev. Biol. Plant 42:324-330.

Grafi, G. and B.A. Larkins. 1995. Endoreduplication in maize endosperm: Involvement of Mphase-promoting factor inhibition and induction of S-phase-related kinases. Science 269: 1262-1264.

Hasselkus, E.R. 1998. A guide to selecting landscape plants for Wisconsin. Univ. Wisconsin Coop. Ext. Publ. A2865:11

Kehr, A.E. 1996. Woody plant polyploidy. Amer. Nurse 183:38-47.

Larkins, B.A., B.P. Dilkes, R.A. Dante, C.M. Coelho, Y. Woo, and Y. Liu. 2001. Investigating the hows and whys of DNA endoreduplication. J. Expt. Bot. 52:183-192.

Lim, W.L. and C.S. Loh. 2003. Endopolyploidy in Vanda Miss Joaquim (Orchidaceae). New Phytol. 159:279-287.

Matzk, F., K. Hammer, and I. Schubert. 2003. Coevolution of apomixis and genome size within the genus Hypericum. Sex. Plant Reprod. 16:51-58.

McCoy, J.-A. and N.D. Camper. 2002. Development of micropropagation protocol for St. John's Wort (Hypericum perforatum L.). HortScience 37:978-980.

Mishiba, K., T. Okamoto, and M. Mii. 2001. Increasing ploidy level in cell suspension cultures of Doritaenopsis by exogenous application of 2,4-dichlorophenoxyacetic acid. Physiol. Plant. 112:142-148.

Morejohn, L.C., T.E. Bureau, J. Molè-Bajer, A.S. Bajer, and D.E. Fosket. 1987. Oryzalin, a dinitroaniline herbicide, binds to plant tubulin and inhibits microtubule polymerization in vitro. Planta 172:252-264.

Moura, M. 1998. Conservation of Hypericum foliosum Aiton, an endemic Azorean species, by micropropagation. In Vitro Cell. Dev. Biol. Plant 34:244-248.

Moyne, A.L., F. Souq, L.H. Yean, S.C. Brown, M. Boulay, and B.S. Sangwan-Norreel. 1993. Relationship between cell ploidy and regeneration capacity of long term Rosa hybrida cultures. Plant Sci. 93:159-168.

Murashige, T. and F. Skoog. 1962. A revised medium for rapid growth and bioassays with tobacco cultures. Physiol. Plant. 15:473-479. 
Murch, S.J., K.L. Choffe, J.M.R. Victor, T.Y. Slimmon, S. Krishnaraj, and P.K. Saxena. 2000. Thidiazuron-induced plant regeneration from hypocotyl cultures of St. John's wort (Hypericum perforatum). Plant Cell Rpt. 19: 576-581.

Pretto, F.R. and E.A. Santarém. 2000. Callus formation and plant regeneration from Hypericum perforatum leaves. Plant Cell Tissue Organ Cult. 62:107-113.

Pyke, K.A., J.L. Marrison, and R.M. Leech. 1991. Temporal and spatial development of the cells of the expanding first leaf of Arabidopsis thaliana (L.). Heynh. J. Expt. Bot. 42:1407-1416.

Ranney, T.G. 2006. Polyploidy: From evolution to new plant development. Combined Proc. Intl. Plant Prop. Soc. 56:137-142.

Roels, S., M. Escalona, I. Cejas, C. Noceda, R. Rodriguez, M.J. Canal, J. Sandova, and P. Debergh. 2005. Optimization of plantain (Musa AAB) micropropagation by temporary immersion system. Plant Cell Tissue Organ Cult. 82:57-66.
Rossetto, M., K. Dixon, and E. Bunn. 1992. Aeration: A simple method to control vitrification and improve in vitro culture of rare Australian plants. In Vitro Cell. Dev. Biol. Plant 28:192-196.

Santarém, E.R. and L.V. Astarita. 2003. Multiple shoot formation in Hypericum perforatum L. and hypericin production. Braz. J. Plant Physiol. $15: 43-47$.

Siragusa, M., A. Carra, L. Salvia, A.M. Puglia, F. De Pasquale, and F. Carimi. 2007. Genetic instability in calamondin (Citrus madurensis Lour.) plants derived from somatic embryogenesis induced by diphenylurea derivatives. Plant Cell Rpt. 26:1289-1296.

Škof, S., B. Bohanec, D. Kastelec, and Z. Luthar. 2007. Spontaneous induction of tetraploidy in hop using adventitious shoot regeneration method. Plant Breed. 126:416-421.

Touchell, D., J. Smith, and T.G. Ranney. 2008. Organogenesis from Hypericum frondosum leaves. Proc. SNA Res. Conf. Annu. Rpt. 53: $222-225$.
Väinölä, A. 2000. Polyploidization and early screening of Rhododendron hybrids. Euphytica 112:239-244.

Valente, P., W. Tao, and J.-P. Verbelen. 1998. Auxins and cytokinins control DNA endoreduplication and deduplication in single cells of tobacco. Plant Sci. 134:207-215.

van Tuyl, J.M., B. Meijer, and M.P. van Diën. 1992. The use of oryzalin as an alternative for colchicine in in vitro chromosome doubling of Lilium and Nerine. Acta Hort. 325:625-629.

Wang, Y.F., Y.F. Sun, R.M. Zhou, L.L. Shan, and R.J. Lu. 2007. In vitro culture and tetraploid induction of Hypericum perforatum L. Acta Agr. Shanghai 23:14-17.

Werbrouck, S.P.O., M.S. Strnad, H.A. Van Onckelen, and P.C. Debergh. 1996. Meta-topolin, an alternative to benzyladenine in tissue culture? Physiol. Plant. 98:291-297.

Wojtania, A., E. Gabryszewska, and A. Marasek. 2004. Regeneration of Pelargonium $\times$ hederaefolium 'Bonete' from petiole explants. Acta Physiol. Plant. 26:255-262. 